Historic, Archive Document

Do not assume content reflects current scientific knowledge, policies, or practices. 

 \\ PRICE LIST FOR 1907 BELle COTTAGE NURSERIES
}

\author{
GEO. J. KELLOGG \& SONS, PROPS. \\ JANESVILLE, WISCONSIN
}

To our old customers and to others who receive this list, we offer a large stock of trees and plants of the best standard varieties, well grown and thriftm handled and packed under cover, with the least possible exposure, and we warrant same to arrive at destination in good order, after which our responsibility ceases. We do not employ agents, as we prefer to sell direct to the planter, which is more satisfactory to ail parties. If you buy direct from a reliable form you save a large commission from the middleman.

We thank you for past favors and solicit your further orders, and careful attention will be given to all business sent us. To those wishing reference we refer to the Merchants' and Mechanics' Savings Bank of this city.

GUARANTEE-We exercise the greatest care to have all stock true to name and grade and satisfactory in every way. but it is hereby agreed between the purchaser and ourselves that should any stock not prove true to name, on proper proof. we will replace it or refund the purchase price, but shall not be held for further damage.

Claims for shortage, errors, etc.. must be made within five davs of receipt of stocls. Mistakes do occur, but we are always willing to correct same. But in making complaints be reasonable.

ORDERS are acknowledged at nncel and should you fail to receive an answer in ten days, write us again. Write your name and address plainly and give full shipping directions.

Order early before the assortments are broken and thereby avoid disappointment and possibly delay.

Orders shipped in rotation and late ones must take their turn.

SUBSTITUTION-When any variety or grade is exhausted we reserve the right to substitute, or to put in a smaller grade of trees, unless otherwise stated in the order, but in this case the true name will always be on such stock, and full value sent if smaller grades are used. We furnish 6 at dozen, 50 at hundred and 500 at thousand rates, and allow an assortment of varieties.

Plant with Care, and see that the earth is nacked firmly about the roots and that all trees planted are thoroughly wet down and well mulched. The ground should be well prepared before planting and given thorough cultivation afterwards.

On receipt of stock, dip roots in water and bury in moist ground, except strawberry and raspberry plants, which should not be wet, but open the bundles and spread out, packing the soil firmly to the roots. All stock should be set out as soon as possible.

We can supply Tree Protectors to those wanting them.

To parties wishing same, a short list of instructions in regard to planting and cultivation of stock will be mailed on request.

TERMS-Cash with order or before shipment.

Any information not given in this list will be furnished on application.

PACKING CHARGES-Bales of less than 50 trees, 25c; 50 to 100 trees, 50c; 150 trees, $75 \mathrm{c}$. Where more than 150 trees are ordered they' will have to be boxed, in which case no charge will be made for packing except the cost of boxing, as follows: 30 by 30 inch heads, $\$ 2.50 ; 24$ by 24 inch, $\$ 2.00$ : 18 by 18 inch, $\$ 1.50$; all 8 to 10 feet long. No charge for packing small fruit plants at the list price, or for cartage. We have United States and American Express Companies and C. \& N. W. R. R. and C. M. \& St. P. R. R. Companies, 
6 to 7 feet....................................... $\$ 2.00 \quad \$ 15.00$

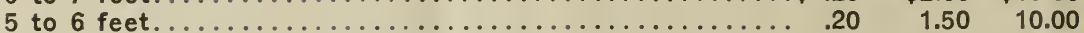

4 to 5 feet................................... $15 \quad 1.00 \quad 5.00$

Thousand rates quoted on application.

Varieties marked thus * are recommended for the extreme north.

We have some varieties in stock not listed. Read the first page carefully.

\section{SUMMER VARIETIES.}

TETOFSKI-(Origin Russia) Medium size; roundish conical; yellow, striped and splashed with red; juicy, sprightly sub-acid; season, August.

YELLOW TRANSPARENT-(Russia) Medium, roundish conical, light yellow, juicy, sub-acid. One of the best early varieties. July-August.

*DUCHESS-(Russia) Large roundish flattened, light yellow covered with stripes and splashes of dark crimson, firm, sub-acid. AugustSeptember.

IOWA BEAUTY-(Iowa) Large, roundish, irregular, golden yellow, striped dark red, juicy, acid. September.

\section{FALL VARIETIES.}

MCMAHON-(Wis.) Large, roundish, slightly flattened, light yellow to white, crisp, juicy, sub-acid. October.

WOLF RIVER-(Wis.) Very large, roundish, irregular, yellow, covered with dark crimson, coarse grained, juicy. October-December.

*WEALTHY-(Minn.) Medium to large, roundish, oblate, striped, bright crimson to dark solid red. A very attractive fruit. Very juicy, subacid. October-January.

PRICES SWEET-Medium, oblong conical, greenish yellow with dull red splashes, juicy, sweet. September-October.

FALL AND WINTER.

*LONGFIELD-(Russia) Medium, roundish conical, light yellow with red blush, very juicy, sub-acid. October-December.

PLUMB'S CIDER-Above medium, roundish, oblong, greenish yellow, striped dull red, firm, juicy. October-January.

*PATTEN'S GREENING-(Iowa) Large, round, slightly flattened, yellowish green with bronze blush, sub-acid. October-Jnuary.

FAMEUSE OR SNOW-Medium, roundish, flattened, deep solid red, sometimes striped, juicy, fine grained, mild sub-acid. October-January.

*PEERLESS-(Minn.) Medium to large, roundish, conical, greenish, striped with dull red, firm, sub-acid. October-January.

\section{WINTER VARIETIES.}

PEWAUKEE-(Wis.) Large, roundish, irregular, striped with dull red, mild sub-acid. December-February.

*NEWELL-(Wis.) Large, roundish, deep yellow with slight blush, juicy, sub-acid. January-March.

AVISTA-(Wis.) Medium, oblong conical, yellowish green, red striped, mild sub-acid. Jnuary-March.

EUREKA-(Wis.) Large, roundish, light yellow with crimson stripes, juicy, mild sweet. January-March.

RAMSDELL'S SWEET-(Conn.) Medium to large, oblong conical, red, striped to dark red, firm, very sweet. October-February.

TALMAN SWEET-Medium, round, whitish yellow, juicy, mild sweet. January-March.

MINKLER-Medium, roundish, flattened, yellow, striped with dull red, juicy, mild sub-acid. January-May.

MANN-(N. Y.) Large, slightly flattened, green to whitish yellow, juicy, fine grained, sub-acid. February-March.

*SCOTTS WINTER-(Vt.) Medium, roundish, oblate, red striped to dark red, juicy, sub-acid. February-April.

SALOME-(Ill.) Medium, roundish, conical, greenish, striped, light to dark red, mild, sub-acid. February-April.

DOMINION WINTER-Medium, roundish, oblate, light to dark red striped, juicy, mild sub-acid. October-January. 
*N. W. GREENING-(Wis.) Large, roundish, oblong, regular, yellowish green, firm, mild sub-acid. February-May.

BEN DAVIS-Large, roundish, conical, light to dark red, striped, coarse grained, mild sub-acid. February-May.

GANO-(Mo.) A seedling of Ben Davis and similar to it in shape and size, but more highly colored and of better quality. Largely grown for market. February-May.

*WALBRIDGE-(Ill.) Medium roundish, oblate, green yellow with pale red stripes, mild sub-acid. February-May.

\section{CRABS}

HISLOP-Large, roundish, tapering, dark solid red, acid. October.

*MARTHA-Large, oblate, bright red, sometimes striped, acid. OctoberDecember.

*SWEET RUSSET-Large, roundish, oblong, greenish yellow, mild sweet. September.

*VIRGINIA-Medium, roundish, flattened, nearly solid red, very juicy, acid. September-November.

*WHITNEY NO. 20-Large, roundish, oblong, waxen yellow covered with dark red, juicy, mild sub-acid. August-September.

\section{PEARS}

each doz. 100

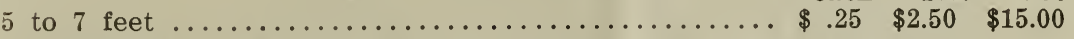

DUCHESS DE ANGOULEME-Very large, oblong, greenish yellow, juicy, good quality. July.

BARTLETT-Large, oblong, yellow, fine grained, juicy, sweet. September.

FLEMISH BEAUTY-Large, yellow with redish brown tinge, juicy, sweet. September.

CLAPP'S FAVORITE-Large, ovate, pale yellow, juicy, melting. September. KIEFFER-Large, oval, yellow with light blush, coarse grained, very hardy. October-December.

\section{PLUMS}

each doz. 100

feet............................... \$ $.35 \quad \$ 3.60 \quad \$ 20.00$

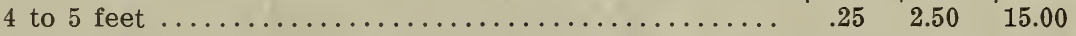

*DESOTO-Large, oval, light yellow to red, sometimes mottled, juicy, good quality. An early and regilar bearer, producing large crops. September.

*FOREST GARDEN-Large, roundish oblong, deep red with yellow tinge, firm, sub-acid. September.

OCHEDA-Medium to large, roundish oblong, mottled reà, rich, sweet. September.

LOMBARD-Large, oblong, slightly flattened, purp'ish red with blue bloom, flesh firm, meaty; mild sub-acid. September.

ROLLINGSTONE-Medium to large, slightly flattened, color mottled red to purple; flesh firm, sweet. September.

WOLF-Large, round, yellow mottled with dark red, good quality. September.

*WYANT-Large, oblong, flattened, purple, red, firm, meaty, good quality. One of the best American varieties. September.

*SURPRISE-Very large, roundish oval, bright crimson, sometimes mottled, vigorous upright grower, an early bearer and a very choice variety. Flesh firm, meaty, sweet. August. Price of Surprise same as cherries.

\section{CHERRIES}

11. each doz. 100

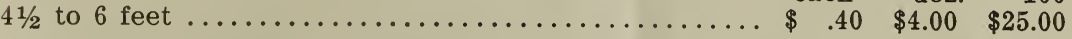

*EARLY RICHMOND-An early variety of extreme hardiness bearing large annual crops of medium sized fruit, light to dark red, very juicy. Season June.

*MONTMORENCY-Large, bright, crimson, very juicy, strong upright grower and one of the hest late varieties. Season July.

ENGLISH MORRELLO-Large, dark, red, juicy, tree somewhat dwarf in growth. July. 


\section{CURRANTS-Two Years}

WRAGG-Large, dark crimson, nearly black when ripe,

VICTURIA-A standard market variety, always reliable, dark red, very productive, berry medium to large, good quality, season early..................\$.60

PRINCE ALBERT-Large size, bright red, productive,

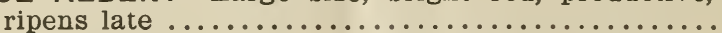

NORTH STAR-Strong, vigorous grower, medium size,

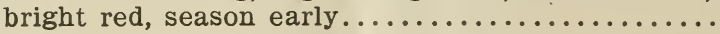

L. B. HOLLAND-A medium sized late variety; a strong grower and very prolific; bush attains to immense size; fruit light red, hanging in long

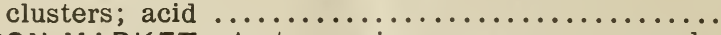

LONDON MARKET-A strong vigorous grower, an early and abundant bearer, berry of large size and deep rich crimson, fine quality; bunches long, mid-

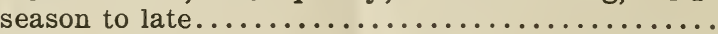

WILDER-A new variety largely grown for market, bush and berry very large, dark rich red and good quality. Always brings the top prices..............

POMONA-A new early variety, very desirable, medium to large size, bright crimson, very productive, of good quality, a good shipper and a leading

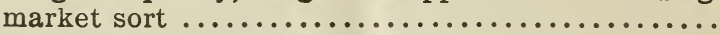

WHITE GRAPE-A large sized standard white variety of

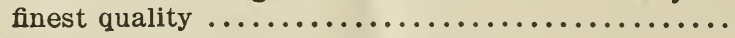

$\$ 2.50 \$ 20.00$

$\begin{array}{lll}.60 & 2.50 & 20.00\end{array}$

$\begin{array}{lll}.60 & 2.50 & 20.00\end{array}$

$2.50 \quad 20.00$

\section{GOOSEBERRIES}

DOWNING-Strong, upright vigorous grower, very productive. Berries large size, bright green, and of first quality. The standard market variety.......\$1.25

HOUGHTON-Spreading grower, medium size, pale red,

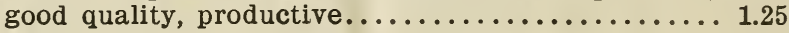

\section{RASPBERRIES}

*LOUDON-Large size, dark red, mid-season, upright grower, very productive, a hardy, market variety. $\$ .50$

CUTHBERT-Strong vigorous grower, berries very large, conical rich crimson, very firm, productive,

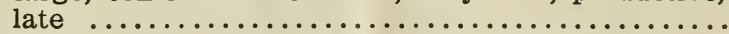

*TURNER-Early, medium size, bright scarlet, vigorous grower, inclined to be soft, quality the best........

COLUMBIAN-Large, purple, firm, vigorous grower and

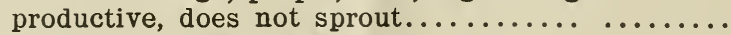

*CUMBERLAND-Very large, black, firm and of first quality. Strong vigorous grower and very pro-

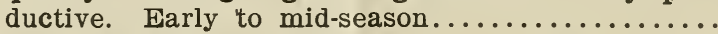

GREGG-Large size, late, firm and of first quality,

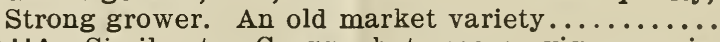

NEMAHA - Similar to Gregg, but more vigorous in

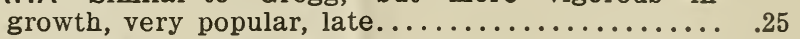

*OLDER-Large roundish, firm, early and a sure cropper, vigorous grower and very hardy $\ldots \ldots \ldots \ldots \ldots \$ .25$

KANSAS - Strong grower, productive, early, firm enough

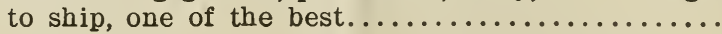

\section{BLACKBERRIES}

ANCIENT BRITON-A standard market variety, fruit large, juicy, fine, strong grower, producing profitable crops. Season late.......................

SNYDED-Strong vigorous grower and very hardy, medi-
um to large size, very productive, good quality, ripens early 


\section{GRAPES}

\section{Strong 2-year vines.}

each doz.

100

*CONCORD-An old standard variety succeeds everywhere, very productive, berry large, juicy, deep glossy black, season September 10 to $25 \ldots \ldots \ldots \ldots$

*WORDEN-A choice early variety, large glossy black, very sweet, grows in large, compact bunches.....

*MOORE'S EARLY-Large, juicy, fine quality, bunch medium compact, black, two weeks earlier than

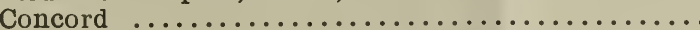

BRIGHTON-Medium to large, dark brownish red, rich

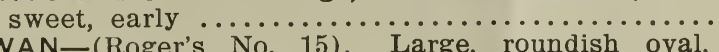

AGAWAN-(Roger's No. 15), Large, roundish oval,

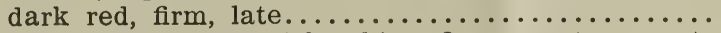

NIAGARA-Large, yellowish white, firm, meaty, sweet,

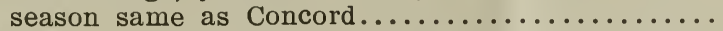

DIAMOND-(Moore's Diamond), Medium size, compact bunch, greenish white, juicy, tender, mid-season...

\section{ASPARAGUS}

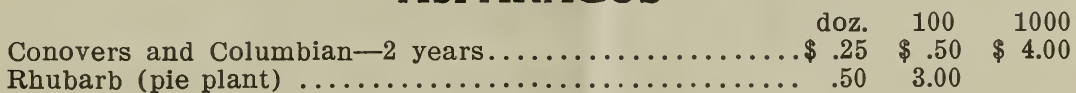

\section{TREES}

FOREST TREES-

6 to 7 feet................................. $\$$. $\$ 1.00 \quad \$ 10.00$

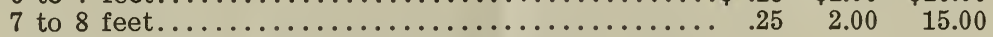

Ash, Box Elder, Elm, Soft Maple, Am. Linden,

Catalpa, Native Birch, Carolina Poplar.

$\mathrm{BIRCH}-$

Cut Leaved Weeping, finest ornamental tree for

lawn or cemetery, 6 to 8 feet................. $\$ 1.00 \$ 10.00$

\section{EVERGREENS-}

Norway Spruce, 2 to 3 feet................ $\$ .25 \quad \$ 2.00 \$ 15.00$

Norway Spruce, 12 to 18 inches................... $15 \quad 1.50 \quad 10.00$

Balsam Fir, 2 to 3 feet.......................... $25 \quad 2.00 \quad 15.00$

Am. Arborvitae, 2 to 3 feet.......................... $25 \quad 2.00 \quad 15.00$

Am. Aborvitae, 18 to 24 inches.................. $15 \quad 1.25 \quad 8.00$

Pines, 2 to 3 feet........................... $20 \quad 2.00 \quad 15.00$

Other sizes of forest trees and evergreens priced on application.

\section{ROSES}

Hybrid Perpetuals each doz. 100

EARL OF DUFFERIN-Crimson, large full and fragrant.

GEN. JACQUEMINOT-Deep red, free bloomer, fragrant, large size, one of the finest.

GEN. WASHINGTON-Dark red, flowers large and very double, free bloomer.

M. P. WILDER-Deep red, one of the finest red roses. Large size and full. Free bloomer.

ULRICH BRUNNER-Bright red, large size, vigorous.

PAUL NEYRON-Dark pink very large, strong vigorous grower and a free bloomer.

MAGNA CHARTA-Bright pink, large size, fragrant. Very fine.

CLIO-Pink, large, fine in form either as bud or open flower. Very free bloomer. The finest pink Hybrid Perpetual.

JOHN HOPPER-Pink, large and full and a free bloomer, fragrant.

MADAM PLANTIER-White, large size and very full, very hardy.

COQUETTE DES. BLANCHE-White, medium size and full. Blooms in clusters. One of the best. 


\section{CLIMBERS}

BALTIMORE BELLE-Blush white changing to white, blooms in clusters, flowers large and full.

QUEEN OF PRAIRIE-Pink, large, full, vigorous grower and blooms freely.

CRIMSON RAMBLER-The most beautiful crimson climbing rose. Flowers in large pyramidal clusters of from 30 to 40 blooms. Strong grower and hardy.

WHITE AND YELLOW RAMBLERS-Similar to the Crimson Rambler. DOROTHY PERKINS-Beautiful shell pink, full and double, large size for cluster rose. Closely resembles the Crimson Rambler.

\section{SHRUBS}

25 c each. $\$ 2.50$ per dozen.

SPIREA VAN HOUTTI-(Bridal Wreath) Large white flowers, early bloomer. "A snow bank of bloom." The finest of all the shrubs.

SPIREA BUMALDA-Dwarf but vigorous grower, blooms freely during midsummer and autumn. Rose color. Very desirable.

DEUTZIA-Pride of Rochester, one of the most beautiful and desirable of flowering shrubs, vigorous grower and free bloomer. White. June.

WEGELIA ROSEA-Blossoms in June, large trumpet shaped flowers of rose color that fade to nearly white, very desirable.

WEGELIA VARIEGATED-Resembles Wegelia Rosea, has variegated green and white leaves, very choice.

HYDRANGEA P. G.-A fine shrub, blooms August and September, large, white flowers pyramidal shape, often a foot long.

SYRINGA-A large vigorous upright growing shrub. Flowers white, blooms very freely in June.

LILACS-Purple, white and variegated.

SNOWBALL-A well known shrub, large white flowers latter part of May. HONEYSUCKLE-(Bush) Red and white. Blooms in June.

SCARLET TRUMPET HONEYSUCKLE-(Climbing) Red, strong rapid grower, blooming all summer.

BITTER SWEET-One of the best native climbing vines, a vigorous grower and free bloomer, and very ornamental, even in late fall with its bright red berries, which it retains all winter; needs no protection.

GOLDEN GLOW-(Rudbeckia) A hardy perennial grows five to seven feet, blooms from summer 'till fall. A good plant for border or background.

JAPAN IVY - One of the hardy climbers, clings to the smoothest surface.

AMERICAN IVY-(Virginia Creeper) Native climber too well known to need description.

\section{CLEMATIS}

2-year, 35c each. $\$ 3.00$ per dozen.

JACKMANII-Large rich violet purple.

HENRYII-Very large single white.

MAD. E. ANDRE-Crimson red, large free bloomer.

PANICULATA-Very rapid grower and profuse bloomer. Thrives anywhere. Blooms from summer 'till frost, flowers small, pure white. The most satisfactory of all the Clematis.

PEONIES each doz. 100

PEONIES-Red, white and pink..................25 $\$ 2.50 \quad \$ 15.00$

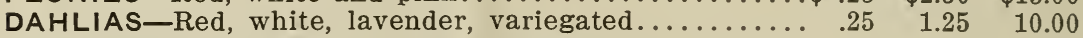

GLADIOLIA-Of these we have a fine stock of mixed

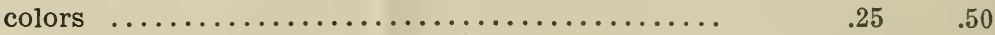

\section{STRAWBERRIES}

To this department we give special attention and the plants we offer are equal to any grown, are carefully graded and no small, inferior ones sent out; they are fresh dug from new beds that have never fruited, and are shipped to our customers while in fresh, vigorous condition. They are not held in the packing house 'till half their vitality is gone. We ship in baskets or light boxes; and all plants are neatly trimmed and tied in bunches of 25 . They are carefully packed and we guarantee them to arrive in good condi- 
tion when shipped by express; we do not recommend freight shipments with this class of stock.

Those varieties which are strong growers and made a heavy stand of plants are more reliable than those which only make a moderate growth. When we prove a variety to be inferior to the standards it is discarded, and while all varieties may not succeed the same as with us we judge them by actual test in field culture grown with the object of marketing fruit at a profit.

Plant two by four feet on thoroughly prepared ground, cultivate often and when you have a solid matted row two feet wide, restrict the growth, (don't let a weed grow), mulch in fall with straw or some coarse material free from weed seed, remove a part of it the following spring and place between the rows as mulch.

Varieties marked "Imp." are imperfect in blossom and must be set with "Per." perfect flowering kinds.

Varieties marked * we especially recommend for general cultivation.

NOTICE-The prices below are for plants spring of 1907; to those needing plants the coming August or September we will quote prices after July 1.

We carry a stock of berry boxes and will quote prices on application.

AROMA-Per. Medium to large, roundish conical form, doz. $100 \quad 1000$ berry bright red and of good quality. Plant strong but not a free runner; moderately productive,

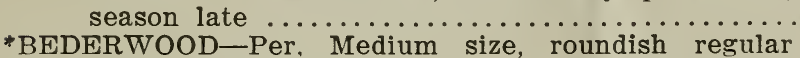
form, moderately firm, very productive and of good quality. An early variety of strong vitality

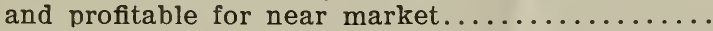

*CLYDE-Per. Large to very large roundish regular form, bright scarlet, moderately firm, good quality, mid-season to late. A strong plant but not a free runner, yet producing large crops of fine fruit which hold to the end of season. Is one of the best all 'round varieties for home or market...

CRESCENT-Imp. Medium size, plant a vigorous grower and very productive. Berries run small at last picking but it is still largely grown...............

ENHANCE-Per. Late, very productive, medium to large, irregular shape, a good shipper............

GLEN MARY-Per. Very vigorous and productive, large size, irregular shape, very firm, late, ships well. Does not always ripen evenly, plants are

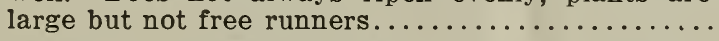

HAVERLAND-Imp. Early, medium size, conical form, light color, inclined to be soft. Plant a good grower and for home market is all right..............

KLONDIKE-Per. Large to very large roundish conical regular form, very productive, late, deep red and of finest quality. A strong grower and one of the

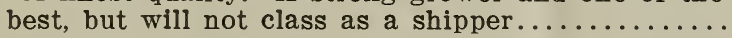

*LOVETT-Per. Medium to large, dark red, conical, very productive, a vigorous grower and one of the best. A good shipper. This is one of the old reliable sorts and seldom fails to produce a large

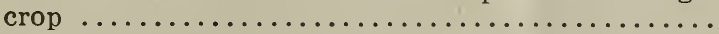

*MARIE-Imp. Medium to large, roundish regular form, early, light colored and of good quality. Plant a vigorous grower and very productive; berries of even size-holding well to end of season. A val-

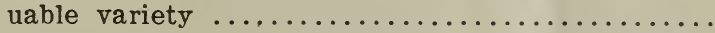

*PARSON'S BEAUTY-Per. Medium to large, roundish, conical form, dark red, firm and a good shipper, mid-season. A large, strong plant and a free runner; produces large crops of fine fruit, berry hold-

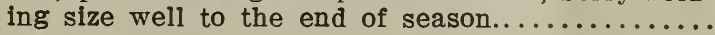


*SPLENDID-Per. Very productive, firm, medium to large, roundish regular form, and of first quality; a vigorous grower but inclined to rust, yet it is

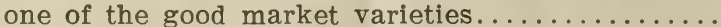

*SAMPLE-Imp. Medium to large, roundish conical, dark red very firm, quality good, a strong vigorous grower and very productive, season late, and a first class market berry. One of the best pistillates we have.

*SENATOR DUNLAP-Per. Medium to large, conical, dark red, firm and of first quality, mid-season. A vigorous grower and usually makes too many plants for best results, unless growth is restricted. It is as productive as Warfield, berries are better colored and a third larger. One of the best market varieties and no list is complete without it.........

*WARFIELD-Imp. Medium size, roundish conical, dark red, very firm and a good shipper. A leading market variety, perhaps more largely grown than any other. This and Senator Dunlap make a fine

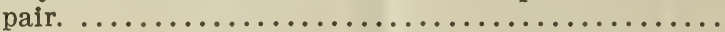

\section{BADGER HEAD_Poland Chinas}

Our herd is now headed by Niagara, No. 116.957, sired by Peacemaker, one of the best boars in the state. He is a line bred Perfection and a long bodied, thick-meated fellow with plenty of quality.

Black Price, No. 112,743, sired by Chief Price, is a Tecumseh bred hog of large size and heavy bone, the typepreferred by some.

The spring pigs will be sired by these and several other good boars, so we can supply stock not related. Sows are mostly mature animals and of good breeding. We have a few sows bred for March and April farrow to offer. Choice spring pigs, when three months old, $\$ 10.00$ each, $\$ 15.00$ a pair. You will get the best ones by ordering early; description and full information to those interested. All stock eligible to record; pedigrees furnished with every animal.

\section{POULTRY}

WHITE WYANDOTTES-The World's Greatest Utility Fowl. This variety is too well known to need a lengthy description. They are good layers, both summer and winter, especially during the winter; are good setters and excellent mothers, yet are not persistently broody. They are of quiet disposition, yet are good foragers, stand confinement well and respond readily to proper care. Chicks are hardy and develop rapidly, being ready for market any time after they weigh two pounds as they are always plump. Pullets often lay at from four to five and one-half months old.

Price, $\$ 1.25$ per 15 eggs. Price of incubator eggs and fowls given on application.

AGRICULTURAL EXPERIMENT STATION, Madison, Wisconsin, September 1, 1906.

This certifies that the nursery premises of GEO. J. KELLOGG \& SON'S, Janesville, Wis, have been inspected by my agent, in accordance with Chap. 180 , Laws of 1899 , and have been found apparently free from the San Jose Scale, or other dangerously injurious insects or plant diseases.

This certificate is void after September 1, 1907, and in any case unless signed on the bottom line by the party to whom it is made out.

W. A. HENRY, Director. 